\title{
THE POTENTIAL INDEMNIFICATION OF SLOVAK FARMERS WITH THE INCOME STABILISATION TOOL
}

\section{Andrea Boháčiková*, Tatiana Bencová, Zuzana Kapustová, Zuzana Strápeková}

\author{
Slovak University of Agriculture in Nitra, Slovakia
}

\begin{abstract}
The risk management tools in agriculture enable farmers to anticipate, avoid and react to shocks and agricultural risks. The Common agricultural policy includes mechanisms to support risk management of the European farmers and respond to crises. An ambition of the recent CAP proposal is to increase the focus on risk management and stabilisation of farmers' income. Under Pillar 2, the CAP offers the support for less favoured farms, which have experienced the production or income loss in the way of insurance premium, mutual funds, and Income stabilisation tool. However, only few European countries have been using these tools operationally. The risk management tools were subjected to criticism, mainly because of many obstacles in their implementation; therefore, since 2018, the risk management toolbox has been further extended. In the paper, we focus on one of the CAP tools from Pillar 2, the Income Stabilisation tool, and examine the potential effect on farmers' indemnification in Slovak agriculture.
\end{abstract}

Keywords: agriculture; risk management; indemnification; income stabilisation tool; CAP

There are many different agricultural risks affecting the farmers; however, in the recent years, the increased attention has been paid to income risk and income stabilisation (Severini et al., 2017). Income risk refers to income volatility, as well as to the low levels of income, that can result in cashflow constraints and lead to farmers' bankrupt (El Benni et al., 2016). The income of a farmer is not only a result of the agricultural production and business activities, moreover, it is affected by the market changes (price change, supply chain, consumer preferences), weather events (droughts, floods, hails), and biological nature of production (diseases of plants, animals, fertilizers).

The income stabilisation has become one of the main objectives of CAP policymakers in the recent years (Meuwissen, 2008). The first proposal for supporting risk management in agriculture appeared after the Health Check 2008, when the risk instruments such as subsidised insurance schemes and mutual funds in the operational programmes for the fruits, vegetables and wine sector were introduced. Number of improvements were suggested during the testing period, which led to the newly introduced risk management, after the 2013 (DG Agri, 2017). Theoretically, farm risk management in the CAP 2014-2020 is provided through commodity programs to stabilize markets against major price disturbances (Pillar 1) and risk management programmes (Pillar 2). Risk management tools proposed in the Regulation (EU) $n^{0} 1305 / 2013$ for the period 2014-2020 allow the Member States to allocate funds of the European Agricultural Fund for Rural Development (EAFRD) to provide financial contributions to income stabilization by 3 instruments: insurance premiums, mutual funds, and Income stabilisation tool (Cordier, 2014; Pigeon et al., 2014; DG Agri, 2017).

The Income Stabilisation Tool, defined in the Article 39 (1305/2013), represents the support for farmers, whose drop of income exceeds $30 \%$ of the average annual income in the preceding three-year period or a threeyear average based on the preceding five-year period excluding the highest and lowest entry (Olympic average). Income refers to the sum of revenues a farmer receives from the market, including any form of public support, deducting input costs. Payments to farmers shall compensate for less than $70 \%$ of the income lost in the year the producer becomes eligible to receive the assistance, regardless the source of income reduction (EC, 2013; El Benni et al., 2016).
Unfortunately, the CAP risk management abilities have remained at the theoretical level in majority of European countries (Meuwissen, 2018). During the 2014-2020 programming period, only 3 countries, Italy, Hungary, and Spain region Castilla y Leon, planned to implement the IST. None of these countries has adopted the measure to the national policy. The lack of experience within the EU and the insufficient guidelines appear as the main obstacles. In Italy, there have been difficulties in monitoring the historical income of farmers (due to loosen accounting rules for Italian farmers), and too high level of the threshold (30\%) (Santeramo, 2018). In Spain, the problem occurred to use IST concerned to specialised dairy producers. In Hungary, a great focus has been to implement IST, but the lack of guidelines, experience and knowledge caused that it has not been developed so far (Cordier, 2020; Vera and Colmenero, 2017).

The legislative amendments to the Rural Development Regulation introduced with the Agricultural Omnibus-package in 2018 were expected to address some of those obstacles and facilitate uptake and implementation of all risk management tools (Reg. 8314/2017). The Omnibus Regulation additional incentive added the sector-specific IST to the toolkit, that might compensate losses exceeding 20\% of average annual income. Moreover, indexes might be used to calculate the annual loss of income of a farmer (both general and sector-specific ISTs) (EC, 2017; Chartier 2017). However, it is still uncertain how much these measures will facilitate the development of IST on the national level. The main objective of the paper is to examine the potential indemnification of Slovak farmers, whose drop of income exceeded $30 \%$ or $20 \%$ loss during the period 2012-2017.

\section{Material and methods}

According to the European Commission, income is defined as the sum of all revenues the farmer receives, including any form of public support, deducting input costs. Several authors examined the effect of IST support in agriculture; however, they did not use the same income category in the studies. Liesivaara et al. (2012) used the profit margin in assessing the feasibility of IST in Finland, El Benni et al. (2016) used net farm income to examine the potential effects of the IST in Swiss agriculture, Pigeon et al. (2012) analysed IST for crop, dairy and cattle farms in the Walloon region in Belgium using farm net value added, 
Table 1 Structure of data

\begin{tabular}{|l|c|c|c|}
\hline \multirow{2}{*}{ Structure of data } & Count & $\%$ & \\
\hline \multirow{2}{*}{ Legal form } & cooperatives & 336 & $51 \%$ \\
\hline & business companies & 317 & $49 \%$ \\
\hline \multirow{2}{*}{ Size } & micro & 107 & $16 \%$ \\
\hline & medium & 342 & $52 \%$ \\
\hline All farms & large & 204 & $31 \%$ \\
\hline \multicolumn{2}{|c|}{ Source: own processing } & $\mathbf{6 5 3}$ & $\mathbf{1 0 0 \%}$ \\
\hline
\end{tabular}

\begin{tabular}{|c|c|c|c|}
\hline \multicolumn{1}{|c|}{ Count } & $\%$ & & \\
\hline $\begin{array}{l}\text { Production } \\
\text { orientation }\end{array}$ & crop farms & 278 & $43 \%$ \\
\cline { 2 - 4 } & animal farms & 375 & $57 \%$ \\
\hline \multirow{3}{*}{ Size of land } & LPIS more than 500 ha & 121 & $19 \%$ \\
\hline & LPIS (500-1,000) & 168 & $26 \%$ \\
\hline & LPIS more than 1,000 ha & 364 & $56 \%$ \\
\hline & & 653 & $100 \%$ \\
\hline
\end{tabular}

Zgajnar (2017) used the gross margin when analysing the indemnification of income risk in Slovenia.

Taking into account the available data, we decided to select the Gross farm income as the income variable to identify the farms that could have received the potential indemnification from IST, if the tool had been implemented in Slovakia. Gross farm income refers to the sum of Sales from products and services (Total output), including Sales from crop production, Sales from animal production and Sales from agritourism, plus the Subsidies of non-investment character, deducting the Input costs. In Slovak accounting, the input costs are recorded in the account Consumption of material, energy and other non-storable supplies (fuels, electricity, seeds and seedlings, fertilizers and pesticides, crop protection products, purchased feeds for animals) and total intermediate consumption. The other costs such as wages, rent and interest paid have not been taken into account, because they do not represent the inputs.

The objective of analysis is to identify the farms that could have been indemnified from Income stabilisation tool's fund, if they had recorded more than $30 \%$, or more than $20 \%$ loss (new Omnibus regulation) compared to the average annual income of the previous three years. The maximal possible financial compensation $70 \%$ is considered, regardless the farmers' financial contribution to the IST fund establishment. Two different thresholds are used to analyse the potential effect after the adjustment of Article 39 (EC Reg. 1305/2013) in 2018. The information from financial statements of 654 farms in the period 2012-2017 are used for the analysis. The data structure is presented in table 1. All the data is obtained from the Ministry of Agriculture and Rural Development of the Slovak Republic.

\section{Results and discussion}

The risk management tools from the Pillar 2 of the CAP are available for Slovak agricultural producers, as for any other European Member state. None of these tools has been implemented in the Slovak Rural Development Programme so far. To deal with agricultural risks, Slovak farmers have ability to use commercial insurance (offered by 3 commercial insurance companies in SR), support of insurance premium for selected crops (specialized to vineyards), and Ad-hoc government measures from the state budget in the case of excessive catastrophic damage, not covered by commercial insurance.

The Income Stabilisation Tool represents a form of financial contribution to mutual funds, providing compensation to farmers in the case of a severe drop in their income. It is similar to a standard mutual fund, with the difference that the former compensates farmers for income losses higher than $30 \%$ of their average annual income in the past three or five years (Olympic average), instead of production losses. The compensation is allowed up to $70 \%$ of income loss. Since 2018 , the originally proposed conditions of the IST has been adjusted, considering the difficulties in the implementation of the IST. The threshold rate changed to $20 \%$, a sectoral IST was added to the toolkit, and the public contribution to the initial capital stock of the mutual fund was allowed.

In the paper, we calculate the potential indemnification for 653 Slovak farmers in the years 2012-2017, using the average annual gross farm income in previous 3 years. We use two different scenarios (with more than $30 \%$ loss and more than $20 \%$ loss) to compare the count of farms and sum of indemnification, the farmers could have received, if the tool had been implemented. In Slovakia, the mutual fund does not exist and the rules such as amount of entry contribution are not stated; therefore, we cannot take into account the initial costs for formers and participants. The results are presented in table 2 and table 3.

The results show that in 2014, 26\% of Slovak farms could have received the indemnification in the total amount of 37.4 mill EUR, if the $70 \%$ of loss would have been covered. The majority of farms suffered greater than $30 \%$ loss, however the new rate criterion would have allowed contribution for additional 70 farmers $(10,7 \%)$ in the total amount 9,6 mill EUR. The range

Table 2 The potential indemnification of Slovak farms in 2012-2017

\begin{tabular}{|l|c|c|c|c|c|c|}
\hline & 2012 & 2013 & 2014 & 2015 & 2016 & 2017 \\
\hline Number of farms & 144 & 112 & 170 & 93 & 100 \\
\hline Percentage of farms & $22.1 \%$ & $17.2 \%$ & $26.0 \%$ & $14.2 \%$ & $15.3 \%$ & $11.0 \%$ \\
\hline Mean & 181916 & 186440 & 216698 & 206804 & 231819 & 194700 \\
\hline Median & 135933 & 137740 & 157385 & 151210 & 157582 & 152337 \\
\hline Max & 962830 & 736526 & 1576237 & 1730838 & 1578112 & 707448 \\
\hline Min & 10630 & 13765 & 10538 & 4087 & 6047 & 5859 \\
\hline The sum of potential indemnification $(€)$ & 26195964 & 20881238 & 37442077 & 19232809 & 23181934 & 14018409 \\
\hline
\end{tabular}

Source: own processing 
Table 3 The effect of changed threshold of IST.

\begin{tabular}{|l|c|c|c|c|c|c|}
\hline & 2012 & 2013 & 2014 & 2015 & 2016 & 2017 \\
\hline More than 30\% loss (original criterion) & 95 & 59 & 100 & 50 & 52 & 49 \\
\hline Number of farms & $14.5 \%$ & $9.0 \%$ & $15.3 \%$ & $7.7 \%$ & $8.0 \%$ & $7.5 \%$ \\
\hline The sum of potential indemnification (€) & 19653040 & 12971121 & 27806668 & 12960661 & 17721007 & 11069947 \\
\hline More than 20\% loss (new criterion) & 49 & 53 & 70 & 43 & 48 \\
\hline Number of farms & $7.5 \%$ & $8.1 \%$ & $10.7 \%$ & $6.6 \%$ & $7.4 \%$ & $35 \%$ \\
\hline The sum of potential indemnification $(\boldsymbol{\epsilon})$ & 6542924 & 7910117 & 9635409 & 6272148 & 5460927 \\
\hline
\end{tabular}

Source: own processing

of financial support varies from the minimum of 10538 EUR to the maximum of 1.58 mill EUR for individual farm. The year 2014 represents the highest potential indemnification with the maximal total amount and number of farms in comparison to other years.

Only $14.2 \%$ of farms would have been eligible for compensation in 2014, from which approximately one half $(7.7 \%)$ suffered the income loss greater than $30 \%$, and the rest of farms recorded the loss from $20-30 \%$. The total indemnification in 2015 would have been 19.2 mill EUR, consisting of almost 13 mill EUR before changed conditions and additional 6.3 mill EUR after. The farm with maximal amount of indemnification would have been supported with 1.7 mill EUR, and the farm with minimal would have received 4087 EUR. The mean value shows that the half of selected farms would have received more than 151210 EUR.

The results in the year 2016 are very similar to the previous year. The 52 farmers (8\%) could have been indemnified after more than $30 \%$ loss in the total amount of 17.7 mill EUR, and other 43 farmers would have met the condition of more than $20 \%$ loss in the total amount of 5.5 mill
EUR. The amount of financial support varies from 6047 EUR to 1578112 EUR, with the mean value 231819 EUR. The lowest number of farms, 11\%, would have been eligible for potential financial contribution from IST in the year 2017. In this year $7.5 \%$ of farms would have be paid almost 11.1 mill EUR to cover more than 30\% loss, and the $3.5 \%$ farmers the additional 2.95 mill EUR (more than 20\% income loss). The median value shows that the half of the farms would have be indemnified with more than 152337 EUR.

The figure 1 shows the comparison of the $\%$ share of farmers, who would have experienced an income loss of more than $30 \%$ or more than $20 \%$ in the years 2012 and 2017. It displays the potential amount of compensation the Slovak farmers could have been supported with if the Income Stabilisation Tool would have been implemented. The lines indicate the \% share of farmers eligible for compensation, and the bars indicate the budget necessary for indemnification in the same years. The Omnibus regulation from 2018 seems to be meaningful, given the potential space for supporting more farmers in loss coverage. For better assessment of the potential effect of IST, we also analysed the years 2012

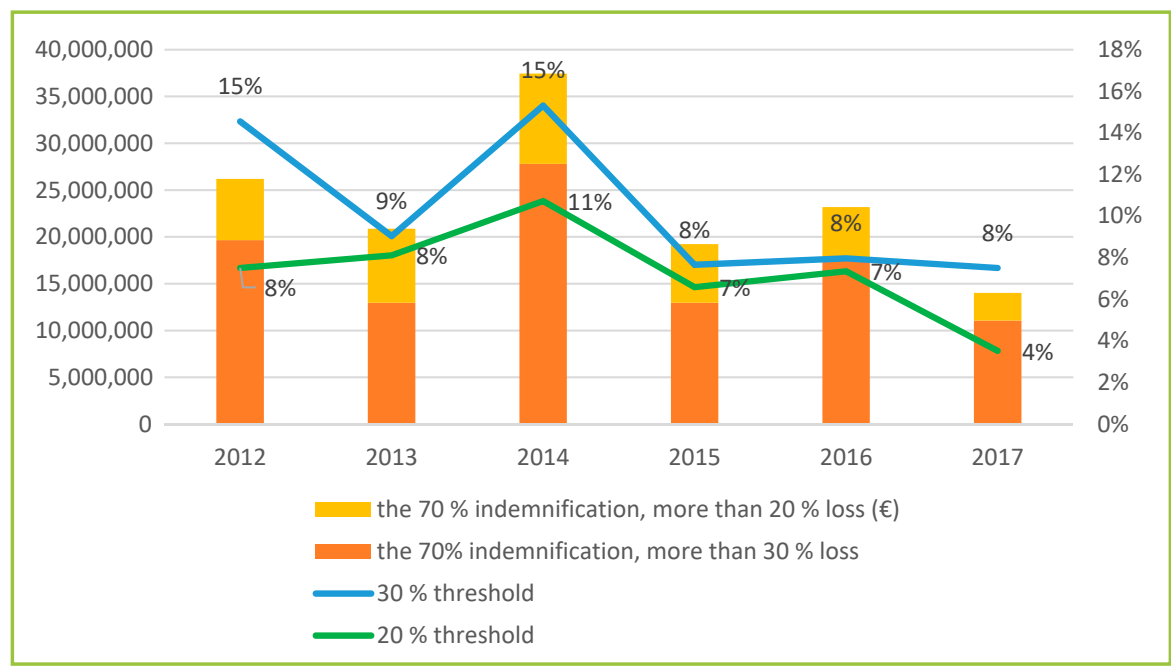

Figure 1 Comparison of indemnification after 2018 Source: own processing and 2013, although the ability to use the Income stabilisation tool belongs to the 2014-2020 Common agricultural policy programme.

\section{Conclusion}

The agricultural risks in Slovakia are usually managed only with the use of commercial insurance products, that do not sufficiently cover all possible risks and damages. In the case of catastrophic or special events, there exist the Ad hoc support from state budget, and the additional support of insurance premiums for vineyards producers. Most of the farmers cover their income losses with the direct payments, which provide a stable form of income regardless the market conditions, rather than with risk management tools.

The risk management tools from the Pillar 2 of the CAP are available for Slovak agricultural producers in the form of insurance premiums, mutual funds, and the income stabilisation tool. None of these tools has been implemented in the Slovak national agricultural policy, because of many obstacles and insufficiencies in the guidelines and lack of experiences. The Income Stabilisation Tool is basically a mutual fund that compensates farmers from the drop of income, instead of production losses. The indemnification is maximally up to $70 \%$ from $20 \%$ loss of average annual income compared to the 3-years average or Olympic average (5-years average without highest and lowest entry). The principal should be that farmers send annually the financial contribution to the mutual fund to create a financial reserve that can be used to compensate income losses independent of the cause. The rules of the IST fund, as well as initial entry contribution depend on the national policymakers' decision. After the establishment, the members of the fund will obtain financial support from Pillar 2 of the CAP.

In the paper, we examined the hypothetical scenarios of the potential financial support the farmers could have received during the period 2012-2017, if the IST were implemented. The $20 \%$ and $30 \%$ loss rate is considered for indemnification to be able to compare the 
amendments of Article 39, EC Regulation 1305/2013 from 2018. It can be concluded that the Income Stabilisation tool implementation in Slovakia would be one of the possibilities to mitigate the income risk of farmers. In the period 2014-2017, the average of $16.6 \%$ of farmers each year could have been compensated with approximately 23.5 mill EUR per year.

However, there are many potential problems of the IST use, such as the lack of willingness of farmers to cooperate, the lack of leadership in the farmers' unions, or usually ineffective co-operation between the Ministry of Agriculture and the farmers' unions. There emerges also the threat of possible adjustment of accounting records in order to obtain IST premium in the future. Therefore, in the first place, the attention to the education and knowledge of farmers in the context of risk management should be paid, which is directly connected to the effort of farmers to implement risk management tools.

\section{Acknowledgement}

This paper was supported by the project VEGA: Impact of the Common Agricultural Policy on the mitigation of income risk in Slovak agriculture and factors determining the level of risk of agricultural companies. Project registration number 1/0338/18.

\section{References}

CHARTIER, 0. - CRONIN, E. - JONGENEEL, M. - VAN ASSELDONK, M. - BERGEVOET, R. - CORDIER, J. - GIELEN-MEUWISSEN, M. - BOCCI, M. 2017. Study on Risk Management in EU Agriculture. DG AGRI. European Commission : Brussels, 2017.

CORDIER, J. 2014. Comparative analysis of risk management tools supported by the 2014 Farm Bill and the CAP 2014-2020. Comparative Analysis of Risk Management Tools supported by the 2014 Farm Bill and the CAP 2014-2020, IP/B/AGRI/IC/2014-044, Parlement Européen, 2014.

CORDIER, J. - SANTERAMO, F. 2020. Mutual funds and the Income Stabilisation Tool in the EU: Retrospect and Prospects. In EuroChoices, vol. 19, 2020, no. 1, pp. 53-58.

DG Agri. 2017. Modernising and simplifying the CAP. Background Document Economic challenges facing EU agriculture, 2017.

EL BENNI, N. - FINGER, R. - MEUWISSEN, M. P. 2016. Potential effects of the income stabilisation tool (IST) in Swiss agriculture. In European Review of Agricultural Economics, vol. 43, 2016, no. 3, pp. 475-502.
EUROPEAN COMMISSION. 2013. Regulation (EU) № 1305/2013 of the European Parliament and of the Council of 17 December 2013 on support for rural development by the EAFRD and repealing EC № 1698/2005. 0J L. In Official Journal European Union L 347/487), 2013, 347, pp. 487-548.

EUROPEAN COMMISSION. 2017. Summary of main changes introduced to the four basic regulations of the CAP through the Omnibus regulation. Retrieved from: https:// ec.europa.eu/agriculture/capoverview/summary-changes-omnibus en.pdf

LIESIVAARA, P. - MYYRA, S. - JAAKKOLA, A. 2012. Feasibility of the income stabilisation tool in finland. No. 706-2016-48385, February $23^{\text {rd }}-24^{\text {th }}$, 2012. Dublin, Ireland.

MEUWISSEN et al. 2018. Report on resilience framework for EU agriculture: Sustainable and resilient EU farming systems (SureFarm) project report, work package D1. 1. Wageningen University \& Research, 2018.

MEUWISSEN, M. P. - VAN ASSELDONK, M. A. - HUIRNE, R. B. (Eds.). 2008. Income stabilisation in European agriculture: design and economic impact of risk management tools. Wageningen Academic Publishers, 2008.

PIGEON, M. - DE FRAHAN, B. H. - DENUIT, M. 2014. Evaluation of the EU proposed farm income stabilisation tool by skew normal linear mixed models. In European Actuarial Journal, vol. 4, 2014, no. 2, pp. 383-409.

REGULATION (EU) No 1305/2013 of the European Parliament and of the Council of 17 December 2013 on support for rural development by the European Agricultural Fund for Rural Development (EAFRD) and repealing Council Regulation (EC) No $1698 / 2005$.

SANTERAMO, F.G. 2018. Imperfect information and participation in insurance markets: evidence from Italy. In Agricultural Finance Review, vol. 78, 2018, no. 2, pp. 193-194.

SEVERINI, S. - TANTARI, A. - DI TOMMASO, G. 2017. Effect of agricultural policy on income and revenue risks in Italian farms: Implications for the use of risk management policies. In Agricultural Finance Review, vol. 77, 2017, no. 2, pp. 295-311.

VERA, A. C. - COLMENERO, A. G. 2017. Evaluation of risk management tools for stabilising farm income under CAP 2014-2020. In Economía agraria y recursos naturales, vol. 17, 2017, no. 1, pp. 3-23.

ZGAJNAR, J. 2017. Analysis of indemnifi cation of income risk at sector level: the case of Slovenia. In Studies in Agricultural Economics, vol. 119, 2017, no. 2, pp. 70-76.

\section{Contact address}

Andrea Boháčiková, Slovak University of Agriculture in Nitra, Faculty of Economics and Management, Department of Finance, Tr. Andreja Hlinku 2, 949 76, Nitra, Slovakia, e-mail: andrea.bohacik@gmail.com 